Vol. 6, No. 1, 2020, pp. 1-4

DOI: https://doi.org/10.29210/120202592

Contents lists available at \ournal IICET

Jurnal EDUCATIO (Jurnal Pendidikan Indonesia)

ISSN: 2502-8103 (Print) ISSN: 2477-8524 (Electronic)

iiCET

Journal homepage: https://jurnal.iicet.org/index.php/jppi

\title{
Kecemasan remaja pada masa pandemi Covid -19
}

\author{
Linda Fitria ${ }^{1}$, Ifdil Ifdil ${ }^{2}$ \\ ${ }^{1}$ Universitas Putra Indonesia YPTK Padang \\ ${ }^{2}$ Universitas Negeri Padang
}

\begin{tabular}{|c|c|}
\hline Article Info & ABSTRACT \\
\hline Article history: & This study objective to analyzed the level of anxiety experienced by \\
\hline Received May $6^{\text {th }}, 2020$ & adolescents during the covid-19 pandemic. This research uses descriptive \\
\hline Revised Jun $10^{\text {th }}, 2020$ & quantitative research methods. The population in this study were adolescents \\
\hline Accepted Jul 21 ${ }^{\text {st }}, 2020$ & aged 12 to 19 years, with a sample of 139 people. The instrument used was a \\
\hline & $\begin{array}{l}\text { questionnaire about anxiety. Data analysis uses descriptive analysis. Based on } \\
\text { the analysis of research data, teenage anxiety during the covid-19 pandemic }\end{array}$ \\
\hline Keyword: & was in the high category at $54 \%$ \\
\hline
\end{tabular}

Anxiety

Remaja

Covid-19

C 2020 The Authors. Published by IICET

This is an open access article under the CC BY-NC-SA license

(https://creativecommons.org/licenses/by-nc-sa/4.0

\section{Corresponding Author:}

Ifdil Ifdil,

Universitas Negeri Padang

Email: ifdil@konselor.org

\section{Pendahuluan}

Pada saat ini dunia sedang dilanda pandemic yang cukup mengkhawatirkan, yaitu COVID-19. Hampir semua negara yang ada di dunia ini mengalami pandemic COVID-19 ini, tidak terkecuali Indonesia (Widiyani, 2020), (Roosinda \& Suryandaru, 2020). COVID-19, adalah jenis virus baru (Zulva, 2020) yang ditemukan pada tahun 2019 dan belum pernah diidentifikasi menyerang manusia sebelumnya (World Health Organization, 2019). COVID-19 merupakan penyakit menular yang disebabkan oleh sindrom pernapasan akut coronavirus 2 (severe acute respiratory syndrome coronavirus 2 atau SARS-CoV-2) (Setiawan, 2020). Penularan virus corona yang sangat cepat karena inilah Organisasi Kesehatan Dunia (WHO) menetapkan virus corona sebagai pandemi pada 11 Maret 2020 (Mona, 2020). Status pandemi atau epidemi global menandakan bahwa penyebaran COVID-19 berlangsung sangat cepat. Beberapa langkah cepat dilakukan oleh pemerintah agar virus corona ini tidak menular dengan cepat, seperti menerapkan work from home (WFH), Social Distancing, dan lain-lain (TURSINA, 2020). Masyarakat juga diedukasi untuk menerapkan pola hidup sehat (Suprabowo, 2020) dengan mencuci tangan dengan sabun sesering mungkin, memakai masker ketika bepergian keluar rumah (Pratiwi, 2020), (Machendrawaty, Yuliani, Setiawan, \& Yuningsih, 2020), serta menjaga jarak (Mardiana \& Darmalaksana, 2020), (Masrul et al., 2020).

Kondisi yang datang tiba-tiba ini membuat masyarakat tidak siap menghadapinya baik secara fisik ataupun psikis (Sabir \& Phil, 2016). Diantara kondisi psikologis yang dialami oleh masyarakat adalah rasa anxiety apabila tertular (Fitria, 2020), (Hanifah, Yusuf Hasan, Nanda Noor, Tatang Agus, \& Muhammad, 2020). Menurut American Psychological Association (APA), kecemasan merupakan keadaan emosi yang muncul saat individu sedang stress, dan ditandai oleh perasaan tegang, pikirang yang mebuat individu merasa khawatir dan disertai respon fisik (jantung berdetak kencang, naiknya tekanan darah, dan lain sebagainya (Okazaki, 1997), (Beaudreau \& O'Hara, 2009). Kartini Kartono bahwa anxiety adalah bentuk ketidakberanian ditambah kerisauan terhadap hal-hal yang tidak jelas (Kartono \& Andari, 1989), (Annisa \& Ifdil, 2016). 
Senada dengan itu, Sarlito menjelaskan anxiety merupakan perasaan takut yang tidak jelas objeknya dan tidak jelas pula alasannya (Sarlito, 2012). Anxiety ini juga dialami oleh para remaja (Gozali, Tjahyo, \& Vidyarini, 2018), karena usia remaja dapat dikatakan usia yang masih labil dalam menghadapi kondisi-kondisi yang tidak terduga (Tjukup, Putra, Yustiawan, \& Usfunan, 2020). Kondisi emosi remaja akan mudah terguncang seperti, anxiety yang berlebihan, ketakutan akan tertular virus ini dan sebagainya (Dani \& Mediantara, 2020). Penelitian ini mengungkap tentang kondisi anxiety yang dialami oleh remaja pada masa pandemic COVID19.

\section{Metode}

Metode yang digunakan dalam penelitian ini adalah kuantitatif deskriptif. sampel penelitian ini adalah 139 remaja dengan menggunakan teknik Purposive Random Sampling. Instrument yang digunakan Skala Kecemasan Remaja. Analisis data menggunakan analisis deskriptif menggunakan dengan bantuan program SPSS.

\section{Hasil dan Pembahasan}

Hasil analisis deskriptif data penelitian tentang anxiety yang dialami remaja pada masa pandemic COVID19 dijelaskan pada tabel berikut ini.

Tabel 1. Anxiety yang dialami remaja pada masa pandemic COVID-19

\begin{tabular}{lccc}
\hline Kategori & Interval & f & \% \\
\hline Rendah & $<12$ & 3 & 2,1 \\
\hline Sedang & $12 \geq \mathrm{X}<24$ & 61 & 43,9 \\
\hline Tinggi & $24-35$ & 75 & 54 \\
\hline
\end{tabular}

Berdasarkan tabele di atas dapat diketahui bahwa tingkat anxiety remaja pada masa pandemic covid-19 berada pada kategori rendah sebesar 2,1\%, kategori sedang 43,9\% dan kategori tinggi 54\%. Dapat juga dilihat dalam histogram berikut:

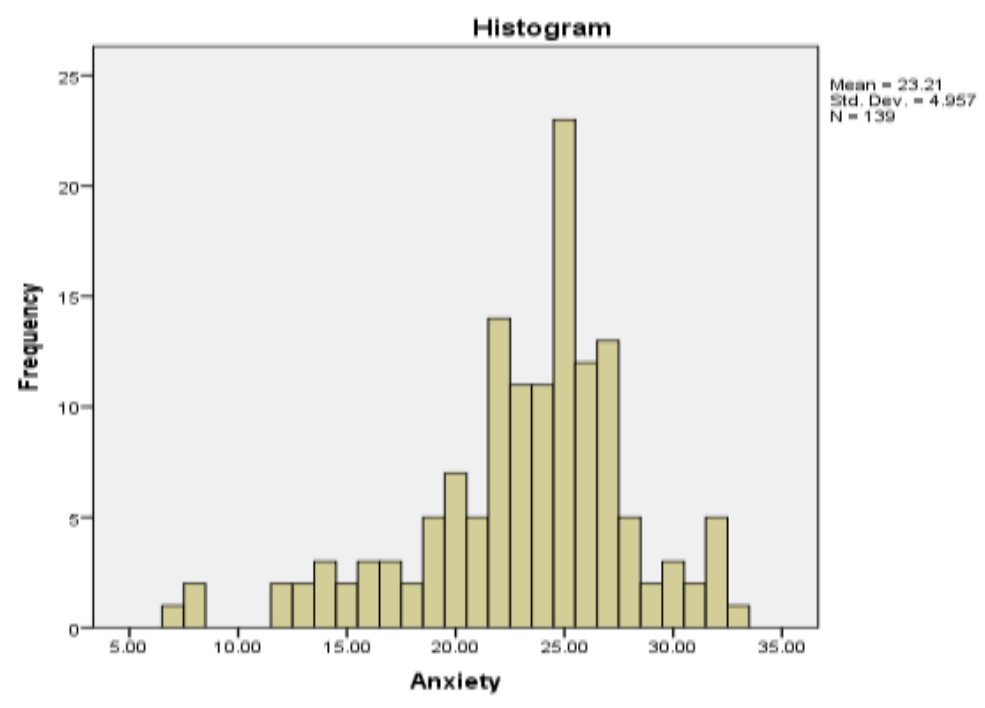

Grafik 1. Diagram Batang hasil pengolahan Data Tentang Tingkat Anxiety Remaja Pada Masa Pandemi Covid-19.

Hasil penelitian penelitian menyatakan bahwa tingkat anxiety remaja 54\% berada pada kategori tinggi. Hal ini kemungkinan besar disebabkan karena kurangnya informasi yang diperoleh remaja terkait dengan pandemi covid-19 ini (Purwanto et al., 2020). Yang ada pada pikiran remaja adalah virus corona sangat berbahaya 
(Zaharah, Kirilova, \& Windarti, 2020), yang apabila seseorang terinfeksi virus ini sulit untuk sembuh (Putri, 2020), dan kebanyakan meninggal. Beberapa faktor yang menyebabkan anxiety pada masa pandemic COVID19 adalah kurangnya informasi mengenai kondisi ini, pemberitaan yang terlalu heboh di media masa ataupun media social (Aulia, 2018), kurangnya membaca literasi terkait dengan penyebaran dan mengantisipasi penularan corona virus.

Anxiety yang dialami remaja ini akan berdampak kepada; 1) Kurang tidu, anxiety dapat menyebabkan insomnia dan masalah tidur lainnya (Sohat, Bidjuni, \& Kallo, 2014). Semakin sedikit tidur maka semakin besar tingkat anxiety. Untuk mengatasi kurang tidur dapat dilakukan dengan fokus pada cara-cara untuk meningkatan kualitas tidur, dengan meningkatnya kualitas tidur maka dapat mengurangi anxiety. Pertahankanlah waktu tidur yang konsisten, batasi konsumsi kopi dan alkohol, matikan alarm, olahraga, dan berjemur pada paparan sinar matahari setiap hari. Hal lain yang dapat dilakukan adalah menjaga kamar tidur tetap sejuk, gelap dan tenang, serta menjauhi gadget agar lebih cepat tidur; 2) Kesulitan untuk fokus, COVID19 telah mengancam kesehatan fisik dan psikis, dan cara hidup sehari-hari. Secara tidak sengaja, setiap hari terus mendengar berbagai berita dan kemudian memikirkan cara-cara untuk melindungi diri dari virus. Masalahnya adalah, selama di rumah juga harus tetap fokus untuk belajar. Akibat pemberitaan COVID19, pikiran menjadi tidak fokus dan sulit berkonsentrasi pada pelajaran (Hanifah, et al., 2020). Cara untuk meningkatkan konsentrasi pada masa pandemic ini adalah dengan mengurutkan apa yang mesti dilakukan, serta jangan lupa juga untuk istirahat yang cukup; 3) Sering lupa, Alexandra Parpura, ahli gerontologi dan pendiri Aging Perspectives di Chevy Chase menjelaskan bahwa anxiety dapat mempengaruhi memori. Apa pun yang merilekskan tubuh akan membantu ingatan, karena relaksasi melibatkan sistem saraf parasimpatis. Kegiatan relaksasi yang baik seperti olahragajuga dapat merelaksasi ingatan. Melakukan permainan yang mengasah kemampuan untuk fokus seperti teka-teki silang, Sudoku, membuat kerajinan tangan, bermain video games, atau bermain alat musik juga dapat membantu untuk mengurangi lupa; 4) Meningkatnya iritabilitas dan mudah marah, anxiety dapat merubah emosi remaja seperti mudah marah. Anxiety yang dialami tiap orang berbeda-beda, tentu saja hal ini berkontribusi terhadap iritabilitas dan kemarahan. Penelitian menunjukkan bahwa anxiety juga dapat memicu emosi ini (Hanifah, et al., 2020).

Kondisi anxiety yang dialami remaja pada masa pandemic ini tentu tidak bisa dibiarkan begitu saja (Harirah \& Rizaldi, 2020). Untuk mengatasi anxiety pada remaja ini peran orangtua sangat dibutuhkan (Fuad \& Budiyono, 2012), diantaranya selalu mendampingi, memotivasi, memberikan pengetahuan tentang COVID-19 ini. Selaku konselor atau guru bimbingan dan konseling ada beberapa hal yang dapat dilakukan untuk membantu remaja mengatasi anxiety adalah dengan memberikan pelayanan seperti layanan konseling individual, bimbingan dan konseling kelompok. Berbagai pendekatan konseling dapat diterapkan dalam kegiatan ini. Berdasarkan beberapa penelitian menyatakan menggunakan pendekan Cognitive Behavioral Therapy (CBT) lebih efektif untuk mengatasi kecemasan (Apriliana, Suranata, \& Dharsana, 2019), dibandingkan pendekatan yang lain.

\section{Kesimpulan}

Berdasarkan hasil penelitian diketahui bahwa tingkat anxiety remaja pada masa pandemic covid-19 berada pada kategori tinggi. Keadaan ini harus direduksi dengan memberikan berbagai pelayanan konseling agar tingkat anxiety remaja tersebut dapat diperkecil. Layanan yang dapat diberikan kepada remaja untuk menurunkan tingkat anxiety dalam masa pandemic covid-19 adalah layanan konseling individual, bimbingan dan konseling kelompok.

\section{Referensi}

Annisa, D. F., \& Ifdil, I. (2016). Konsep kecemasan (anxiety) pada lanjut usia (lansia). Konselor, 5(2), 93-99.

Apriliana, I. P. A., Suranata, K., \& Dharsana, I. K. (2019). Mereduksi Kecemasan Siswa Melalui Konseling Cognitive Behavioral. Indonesian Journal of Educational Counseling, 3(1), 21-30.

Aulia, D. P. (2018). Memerangi Berita Bohong Di Media Sosial (Studi Terhadap Gerakan Masyarakat Anti Fitnah Indonesia). Fakultas Ilmu dakwah dan Ilmu Komunikasi Universitas Islam Negeri Syarif ....

Beaudreau, S. A., \& O'Hara, R. (2009). The association of anxiety and depressive symptoms with cognitive performance in community-dwelling older adults. Psychology and aging, 24(2), 507.

Dani, J. A., \& Mediantara, Y. (2020). Covid-19 dan Perubahan Komunikasi Sosial. Persepsi: Communication Journal, 3(1), 94-102.

Fitria, L. (2020). Cognitive Behavior Therapy Counseling Untuk Mengatasi Anxiety Dalam Masa Pandemi Covid-19. AL-IRSYAD, 10(1). 
Fuad, M., \& Budiyono, A. (2012). Pola Kelekatan di Kalangan Santri Usia Remaja Awal (Studi Kasus di Pondok Pesantren Anwarussholihin Pamujan Teluk, Banyumas). Personifikasi, 3(2), 25-35.

Gozali, M., Tjahyo, J. D. W., \& Vidyarini, T. N. (2018). Anxiety Uncertainty Management (AUM) Remaja Timor Leste di Kota Malang dalam Membangun Lingkungan Pergaulan. Jurnal e-Komunikasi, 6(2).

Hanifah, M., Yusuf Hasan, B., Nanda Noor, F., Tatang Agus, P., \& Muhammad, R. (2020). Kajian Jenis Kecemasan Masyarakat Cilacap dalam menghadapi Pandemi Covid 19. Kajian Jenis Kecemasan Masyarakat Cilacap dalam menghadapi Pandemi Covid 19.

Harirah, Z., \& Rizaldi, A. (2020). MERESPON NALAR KEBIJAKAN NEGARA DALAM MENANGANI PANDEMI COVID 19 DI INDONESIA. Jurnal Ekonomi dan Kebijakan Publik Indonesia, 7(1).

Kartono, K., \& Andari, J. (1989). Hygiene mental dan kesehatan mental dalam Islam. Bandung: Mandar Maju.

Machendrawaty, N., Yuliani, Y., Setiawan, A. I., \& Yuningsih, Y. (2020). Optimalisasi fungsi mesjid di tengah pandemic Covid 19: Telaah syar'i, regulasi dan aplikasi. UIN Sunan Gunung Djati Bandung.

Mardiana, D., \& Darmalaksana, W. (2020). Relevansi Syahid Ma'nawi dengan Peristiwa Pandemic Covid-19: Studi Matan Pendekatan Ma'anil Hadis. Jurnal Perspektif, 4(1), 12-19.

Masrul, M., Tasnim, J. S., Daud Oris Krianto Sulaiman, C. P., Purnomo, A., Febrianty, D. H. S., Purba, D. W., . . Ramadhani, Y. R. (2020). Pandemik COVID-19: Persoalan dan Refleksi di Indonesia. Medan: Yayasan Kita Menulis.

Mona, N. (2020). Konsep Isolasi Dalam Jaringan Sosial Untuk Meminimalisasi Efek Contagious (Kasus Penyebaran Virus Corona Di Indonesia). Jurnal Sosial Humaniora Terapan, 2(2).

Okazaki, S. (1997). Sources of ethnic differences between Asian American and White American college students on measures of depression and social anxiety. Journal of Abnormal Psychology, 106(1), 52.

Pratiwi, A. D. (2020). Gambaran Penggunaan Masker di Masa Pandemi Covid-19 Pada Masyarakat di Kabupaten Muna. Prosiding Nasional Covid-19, 52-57.

Purwanto, A., Pramono, R., Asbari, M., Hyun, C. C., Wijayanti, L. M., \& Putri, R. S. (2020). Studi Eksploratif Dampak Pandemi COVID-19 Terhadap Proses Pembelajaran Online di Sekolah Dasar. EduPsyCouns: Journal of Education, Psychology and Counseling, 2(1), 1-12.

Putri, A. (2020). Penyakit Menular \& Virus Corona.

Roosinda, F. W., \& Suryandaru, Y. S. (2020). Framing of propaganda and negative content in Indonesian media. Jurnal Studi Komunikasi, 4(1), 63-74.

Sabir, A., \& Phil, M. (2016). Gambaran Umum persepsi masyarakat terhadap bencana di Indonesia. Jurnal Ilmu Ekonomi Dan Sosial, 5(3), 304-326.

Sarlito, W. S. (2012). Psikologi remaja. Jakarta: PT. Raja Grafindo Persada.

Setiawan, A. R. (2020). Lembar Kegiatan Literasi Saintifik untuk Pembelajaran Jarak Jauh Topik Penyakit Coronavirus 2019 (COVID-19).

Sohat, F., Bidjuni, H., \& Kallo, V. (2014). Hubungan Tingkat Kecemasan Dengan Insomnia Pada Lansia Di Balai Penyantunan Lanjut Usia Senja Cerah Paniki Kecamatan Mapanget Manado. Jurnal Keperawatan, 2(2).

Suprabowo, G. Y. A. (2020). Memaknai Hospitalitas di Era New Normal: Sebuah Tinjauan Teologis Lukas 10: 25-37. HARVESTER: Jurnal Teologi dan Kepemimpinan Kristen, 5(1), 43-58.

Tjukup, I. K., Putra, I. P. R. A., Yustiawan, D. G. P., \& Usfunan, J. Z. (2020). Penguatan Karakter Sebagai Upaya Penanggulangan Kenakalan Remaja (Juvenile Delinquency). KERTHA WICAKSANA: Sarana Komunikasi Dosen dan Mahasiswa, 14(1), 29-38.

TURSINA, A. (2020). COVID-19 dan lansia: Pusat Penerbitan Unisba (P2U) LPPM UNISBA.

Widiyani, R. (2020). Latar Belakang Virus Corona, Perkembangan hingga Isu Terkini. Retrieved from detik News.

Zaharah, Z., Kirilova, G. I., \& Windarti, A. (2020). Impact of Corona Virus Outbreak Towards Teaching and Learning Activities in Indonesia. SALAM: Jurnal Sosial dan Budaya Syar-i, 7(3), 269-282.

Zulva, T. N. I. (2020). Covid-19 Dan Kecenderungan Psikosomatis. J. Chem. Inf. Model, 1-4. 